\title{
線織面で構成されるラチスシェルの形状最適化 SHAPE OPTIMIZATION OF LATTICED SHELLS CONSISTING OF RULED SURFACE
}

\author{
藤田 慎之輔 ${ }^{* 1}$, 大崎 純 ${ }^{* 2}$, 關 和 也 ${ }^{* 3}$ \\ Shinnosuke FUJITA, Makoto OHSAKI and Kazuya SEKI
}

\begin{abstract}
A shape optimization method is presented for latticed shells using ruled surface. Boundary shape is defined using two Bézier curves, and the points with the same parameter value are connected hy a line to model a ruled surface. The locations of control points of the Bézier curves are considered as design variables of the optimization problem. This way, the number of variables for optimization can be drastically reduced without sacrificing smoothness and complexity of the surface. The total strain energy is minimized under constraint on material volume, and additional constraint is given for the total floor area of the shell to avoid an erroneous solution and divergence in the analysis and optimization processes. In this optimization problem, not only vertical loads but also horizontal loads are considered. While the optimal shape is expected to have a large stiffness, it does not necessarily have enough capacity for the stress limit. Therefore, we solve another optimization problem considering strain energy and stress constraint. The effectiveness of the proposed approach is confirmed through various examples, and the characteristics of the optimal shapes are discussed.
\end{abstract}

Keywords: shape optimization, Bézier curve, nonlinear programming, ruled surface 形状最適化, ベジエ曲線, 非線形計画法, 線織面

\section{1 序}

解析技術の進歩により，最適化手法が建築分野にも取り入れられ， 近年では, 力学的性能を考慮した形状最適化により, シェルの曲面形 状を決定する研究が多く行われている例えば,1-3)。しかし，優れた建 築の実現のためには意匠性, 経済性, 施工性などの非力学的性能も 考慮することが不可欠である。施工性を考慮に入れた研究としては, ラチスシェルの部材の種類を少なくすることを目的とした小河らの 研究 ${ }^{4}$, 可展面となる制約条件を導入した藤田・大崎の研究 5), デー タベースを用いて部材長を数種類に限定する手法を導入した Basso らの研究 6), 部材長の一様化を目的とした藤田・大崎の研究 7), 部材 接合角の一様化を目的とした西森らの研究 8$)$ などが挙げられる。

空間内で直線を曲線に沿って回転移動したときの軌跡として定義 される曲面を線織面という9)。屋根構造の施工の際, 複雑な曲面の 表現は困難を要するが，母線が直線で形成される線織面は，連続体 シェルにおいては型枠作成が容易となり，ラチスシェルにおいては 1 方向の部材がすべて曲げ加工を必要としない直線材となるため, 施 工性に優れた曲面と言える。また，線織面はガウス曲率を曲面の至 るところで 0 とする必要のある可展面よりも幾何学的な制約が小さ く, 形状表現の自由度が高い。特に, 代表的な線織面である HP 曲面
は，これまで多くの構造物に取り入れられている 10)。 本研究では線織面で曲面形状を定義し, 直線となる母線方向に部 材を有するラチスシェルを対象に最適化を行うことで, 施工性を考 慮する。シェルの構造最適化の手法としては，ひずみエネルギーや外 力仕事を最小化する方法 ${ }^{11,12)}$, 座屈荷重を最大化する方法 ${ }^{4,13)}$, 応 力分布を均一化する方法 ${ }^{14,15)}$ などがあり，いずれの手法を採用する かは, 注目する力学的性能によって異なる。本論文では, 力学的な評 価指標としては，剛性を評価する際に良く用いられる指標であるひ ずみエネルギーを採用する。線織面で定義されるラチスシェルを対 象に，長期荷重を想定した鉛直荷重を作用させ，ひずみエネルギー 最小化を目的とした最適化を行うと，鉛直変位を大幅に低減し，施 工性に優れた，剛性の高い形状が得られる。一方で，得られた最適 形状は水平力に対しては必ずしも高い剛性を有さない。そこで，本 論文では，鉛直荷重に加え，地震力を想定した荷重も考慮した最適 化を行うことで，水平荷重に対しても剛性が高く，かつ施工性にも 優れたラチスシェルの形態を創出する。また, 得られた解に対して, 個材座屈を考慮した式である鋼構造設計規準の応力制約を考慮した 最適化を行うことで，剛性のみならず応力に対しても一定のクライ テリアを満足するラチスシェルの形態を創出することを試みる。

\footnotetext{
*1 東京工業大学科学技術創成研究院未来産業技術研究所 助教・博士 (工学)

*2 京都大学大学院工学研究科建築学専攻 教授 · 博士 (工学)

*3 (株)梓設計 修士 (工学) (元広島大学 大学院生)
}

Assist. Prof., Laboratory for Future Interdisciplinary Research of Science and Technology, Tokyo Institute of Technology, Dr.Eng.

Prof., Dept. of Architecture and Architectural Eng., Kyoto Univ., Dr.Eng. Azusa Sekkei, M.Eng. (Former Grad. Stud., Hiroshima Univ.) 


\section{2 線織面の形状表現}

\section{1 線織面の定義}

線織面は次のように表される16)。

$$
S(u, v)=f(u)+v g(u)
$$

ここで, $f(u)$ は基底曲線， $g(u)$ は母線の方向を定めるべクトルであ る。また， $u, v$ はスカラーパラメータである。 $\boldsymbol{g}(u)=\boldsymbol{h}(u)-\boldsymbol{f}(u)$ とし て式(1)を変形すると, 次式となる。

$$
\boldsymbol{S}(u, v)=(1-v) \boldsymbol{f}(u)+v \boldsymbol{h}(u)
$$

$\boldsymbol{h}(u)$ は基底曲線と等しいパラメー夕を持つ曲線であり, $\boldsymbol{f}(u)$ と $\boldsymbol{h}(u)$ の同一のパラメータの点を結んだ直線が母線 $v \boldsymbol{g}(u)$ である。2つの曲 線 $\boldsymbol{f}(u), \boldsymbol{h}(u)$ により曲面形状が表現可能なため, 曲面を最適化する際 の変数の数を大幅に低減でき, 最適解への収束性を向上できる。

\section{2 ベジエ曲線を用いた線織面}

本研究では, 線織面の定義式における曲線 $\boldsymbol{f}(u)$ と $\boldsymbol{h}(u)$ をべジエ 曲線で定義し，それらを連結する直線 $v \boldsymbol{g}(u)$ で定められる線織面を 表現する。

$k$ 次のベジエ曲線 $\boldsymbol{P}_{k}(u)$ を次式で定義する。

$$
\begin{aligned}
& \boldsymbol{P}_{k}(u)=\sum_{i=0}^{k} \boldsymbol{q}_{i} B_{k, i}(u) \\
& \boldsymbol{q}_{i}=\left[\begin{array}{lll}
q_{x, i} & q_{y, i} & q_{z, i}
\end{array}\right]^{\top}
\end{aligned}
$$

ここで、 $\boldsymbol{q}_{i}$ は制御点座標ベクトルである。 $B_{k, i}(u)$ は $k$ 次のバーンス タイン基底関数であり, 次式で定義される。

$$
B_{k, i}(u)=\frac{k !}{i !(k-i) !} u^{i}(1-u)^{k-i} \quad(0 \leq u \leq 1 \quad i=0, \cdots, k)
$$

式 (3) で定義したベジエ曲線を曲線 $\boldsymbol{f}(u)$ と $\boldsymbol{h}(u)$ に代入すると, 線織 面の定義式 $S(u, v)$ は次式で表される。

$$
S(u, v)=(1-v) \sum_{i=0}^{I} q_{i} B_{I, i}(u)+v \sum_{i=0}^{J} q_{I+i+1} B_{J, i}(u) \quad(0 \leq u, v \leq 1)
$$

$I, J$ はそれぞれ $\boldsymbol{f}(u)$ と $\boldsymbol{h}(u)$ のべジエ曲線の次数であり, これらは 必ずしも同一である必要はない。このように，曲線 $f(u)$ と $\boldsymbol{h}(u)$ にべ ジエ曲線を選ぶことで，ごく少数の制御点で様々な曲面形状を効果 的に記述できる。本手法による線織面の概念図を図 1 に示す。図の 例では, $I=J=5$ であり, 可視化のために $u=0.0,0.1, \cdots, 1.0$ のパ ラメータに対応した母線を記述してある。

\section{3 ベジェ曲線の制御点とラチスシェルの節点との関係}

式 (5)の曲面を， $u, v$ 方向にそれぞれ $I^{\prime}$ 個， $J^{\prime}$ 個に分割し，全体 として $n=\left(I^{\prime}+1\right) \times\left(J^{\prime}+1\right)$ 個の節点を配置する。

節点の $x$ 座標を並べたベクトルを次のように定める。

$$
\boldsymbol{r}_{x}=\left[\begin{array}{lllllll}
x_{0,0} & \cdots & x_{0, I^{\prime}} & \cdots & x_{I^{\prime}, 0} & \cdots & x_{I^{\prime}, J^{\prime}}
\end{array}\right]^{\top}
$$

$y, z$ 座標をそれぞれ並べたベクトル $\boldsymbol{r}_{y}, \boldsymbol{r}_{z}$ も同様である。パラメー夕 $k, l$ に対応する節点座標ベクトルを次式で定義する。

$$
\boldsymbol{r}_{k, l}=\left[\begin{array}{lll}
x_{k, l} & y_{k, l} & z_{k, l}
\end{array}\right]^{\top}
$$

このとき, 3 次元空間内の節点と制御点の座標の関係式は次のよう に書ける。

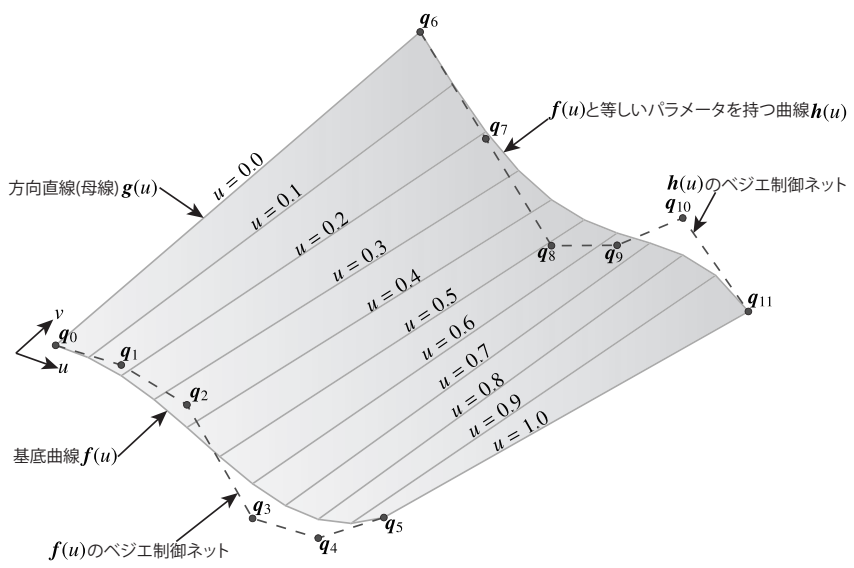

図1 ベジエ曲線で定義された線織面の概念図

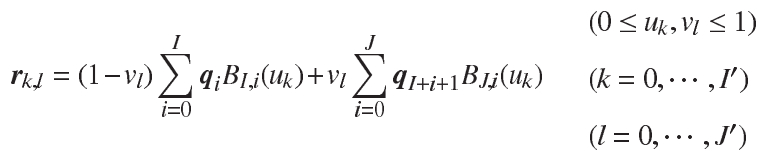

\section{3 剛性に対する最適化問題}

$m$ 個の部材からなる $N$ 自由度のラチスシェルを考える。シェル形 状を決定づける設計変数べクトルを $x$ とする。部材は節点で岡接合 あるいはピン接合されるものとし，静的荷重に対する応答を，梁要 素を用いて解析する。梁要素は 2 節点梁要素 (1 次要素) とする。 $N$ 個 の成分をもつ変位ベクトルを $\boldsymbol{d}(\boldsymbol{x}), N \times N$ の岡性行列を $\boldsymbol{K}(\boldsymbol{x})$ とする。

岡性の向上を目的とした古典的な構造最適化問題では，ひずみ工 ネルギー，あるいはコンプライアンスを最小化する。本研究でも既 往の研究と同様に，剛性の評価指標としてひずみエネルギーを採用 した次のような最適化問題を考える。

$$
\begin{array}{ll}
\text { minimize } & f_{1}(\boldsymbol{x})=\frac{1}{2} \boldsymbol{d}(\boldsymbol{x})^{\top} \boldsymbol{K}(\boldsymbol{x}) \boldsymbol{d}(\boldsymbol{x}) \\
\text { subject to } & g_{1}(\boldsymbol{x})=V(\boldsymbol{x})-\bar{V} \leq 0 \\
& g_{2}(\boldsymbol{x})=\bar{A}-A(\boldsymbol{x}) \leq 0
\end{array}
$$

ここで, 制約 (9b) は材料の体積制約であり， $V(\boldsymbol{x})$ はラチスシェルの 部材の総体積， $\bar{V}$ は $V(\boldsymbol{x})$ の上限值である。体積に上限を設けること で，経済性を考慮できる。

また, 制約 (9c) は水平投影面積に関する制約であり, $A(\boldsymbol{x})$ はラチ スシェルの水平投影面積, $\bar{A}$ は $A(\boldsymbol{x})$ の下限值でスカラーである。節 点の鉛直方向座標を定める変数のみを設計変数 $\boldsymbol{x}$ とする場合には, 平面形状は変化しないので, 制約 $(9 \mathrm{c})$ は不要である。しかし, 水平 方向にも形状修正を行う場合には，平面が消失した非現実的な形状

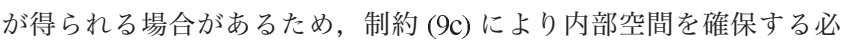
要がある。

弾性解析における全体剛性方程式の求解には Python 言語のライ ブラリである $\mathrm{SciPy}^{17)}$ を利用する。最適化計算には $\mathrm{pyOpt}^{18)}$ を用い, 逐次 2 次計画法 ${ }^{19)}$ により解く。以下に形状最適化のアルゴリズムの 流机を示す。

Step 1 所与の設計条件に応じて, 境界条件，材料定数を定める。設 計変数の初期值 $\boldsymbol{x}^{0}$ を選び， $k=0$ とおく。

Step 2 曲面形状をべジエ曲線を用いた線織面により生成し, 弾性解 
析を行い, 目的関数および制約条件関数の值を計算する。 Step 3 感度解析を行い, 2 次計画問題を解き, 探査方向を求める。 Step 4 現在の点 $x^{k}$ において最適性条件を満たせば終了。そうでな ければラインサーチを㧍こない，設計変数の值を更新する。

Step $5 k \leftarrow k+1$ とし, Step 2 へ戻る。

\section{4 鋼構造設計規準の応力制約を考慮した最適化問題}

シェルの剛性を最大化した形状は，一般に圧縮抵抗型の構造物と なるが，個々の部材に鋼材を使用することが多いラチスシェルは，圧 縮力に弱いため，必ずしも応力に対して有利な形状とはならない。 実務においては，鋼構造設計規準に従った応力のクライテリアの範 囲内で，適切な部材断面を選択することとなる。本研究では，問題 (9) を解いて得られた最適形状に対して, 部材断面形状を決定付ける 変数 $\boldsymbol{a}$ を設計変数とし, 部材検定比に対する制約を付加した次のよ うな最適化問題を考える。

$$
\begin{array}{lll}
\operatorname{minimize} & f_{2}(\boldsymbol{a})=V(\boldsymbol{a}) & \\
\text { subject to } & f_{1}(\boldsymbol{a}) \leq \bar{S} & (i=1, \cdots, m) \\
& g_{3}(\boldsymbol{a})=F_{i j}(\boldsymbol{a})-0.90 \leq 0 & (j=1,2)
\end{array}
$$

問題 (10) は, 許容応力度設計を満足し, 一定の剛性を確保しつつ, 体積を最小化する最適化問題である。ここで， $\bar{S}$ はひずみエネルギー の上限值である。 $F_{i 1}(\boldsymbol{a}), F_{i 2}(\boldsymbol{a})$ は部材 $i$ の両端の検定比であり, 余裕 の無い設計を避けるため, クライテリアを 0.90 に設定している。検 定比の算定は鋼構造設計規準に従い, 長期荷重時における曲げと圧 縮/引張の組み合わせ応力に対して検定比 $F_{i j}(\boldsymbol{a})$ を以下の各式を用い て定める。せん断力は支配的ではないため考慮しない。また，部材 断面はすべて鋼管とする。

$$
\begin{aligned}
& F_{i j}=\left\{\begin{array}{lll}
\frac{\sigma_{c, i j}}{f_{c, i j}}+\frac{\sigma_{b, i j}}{f_{b, i j}} & \cdots \text { if } \quad N_{i j}>0 & (i=1, \cdots, m) \\
\frac{\sigma_{t, i j}}{f_{t, i j}}+\frac{\sigma_{b, i j}}{f_{b, i j}} & \cdots \text { if } \quad N_{i j} \leq 0 & (j=1,2)
\end{array}\right. \\
& \sigma_{c, i j}, \sigma_{t, i j}=\frac{\left|N_{i j}\right|}{A_{i j}}, \quad \sigma_{b, i j}=\frac{\sqrt{M_{z, i j}^{2}+M_{y, i j}^{2}}}{Z_{i}} \\
& f_{t}=f_{b}=F / 1.5, \quad f_{c}= \begin{cases}\frac{1-0.4(\lambda / \Lambda)^{2}}{v} & \cdots \text { if } \lambda \leq \Lambda \\
\frac{0.277 F}{(\lambda / \Lambda)^{2}} & \cdots \text { if } \lambda>\Lambda\end{cases} \\
& \Lambda=\sqrt{\frac{\pi^{2} E}{0.6 F}}, \quad v=\frac{3}{2}+\frac{2}{3}(\lambda / \Lambda)^{2}
\end{aligned}
$$

ここで, $A_{i}, Z_{i}$ はそれぞれ部材 $i$ の断面積および断面係数, $N_{i j}$, $M_{z, i j}, M_{y, i j}$ は部材 $i$ の $j$ 端における軸力および曲げモーメントであ る。なお， $N_{i j}$ は圧縮を正とする。

$f_{c}, f_{t}, f_{b}$ はそれぞれ許容圧縮/引張/曲げ応力度であり，入は圧縮 材の細長比， $\Lambda$ は限界細長比， $E$ はヤング係数， $F$ は鋼材の基準強 度である。座屈長さは部材長をとる。短期荷重に対しては, $f_{c}, f_{t}$, $f_{b}$ は 1.5 倍する。

\section{5 設計外力}

まず，常時荷重として，部材自重に加え，仕上げ重量として $290 \mathrm{~N} / \mathrm{m}^{2}$ の面荷重を鉛直下向きに作用させる。これを荷重ケース $L$ と定義する。

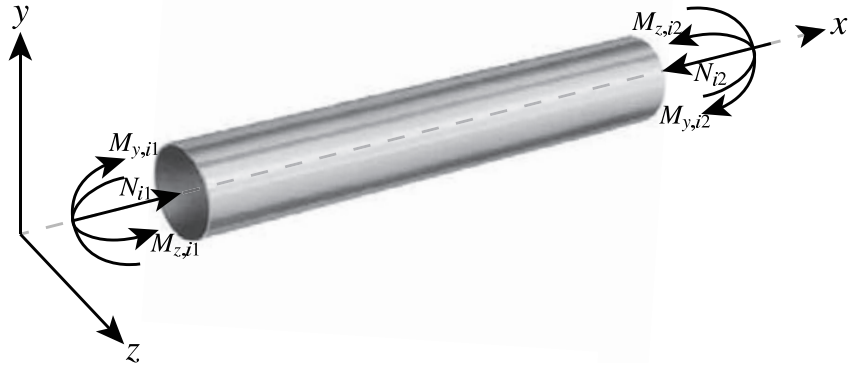

図2 梁要素の断面力

節点数を $n$ とし，常時荷重による等価節点外力の鉛直下向き成分 を $w_{i}(i=1, \cdots, n)$ とする。地震時水平力として, 1 次設計レベルの 検討を想定して, 水平震度を $K=0.30$ とし, $K w_{i}$ の集中荷重を $X, Y$ 方向にそれぞれ作用させる。これらをそれぞれ荷重ケース $X$, 荷重 ケース $Y$ と定義する。各荷重ケースにおける力学量は，両括弧付き の上添え字で区別する。例えば，荷重ケース $L$ におけるひずみエネ ルギーは $f_{1}^{(L)}(\boldsymbol{x})$ のように表現する。

\section{6 線織面ラチスシェルモデル}

最適化のための初期形状として, 図 3 に示すように, 2 つの放物 線状のベジエ曲線をそれぞれ式 (2)の $\boldsymbol{f}(u), \boldsymbol{h}(u)$ にとった線織面で形 状記述される円筒状のラチスシェルを考える。

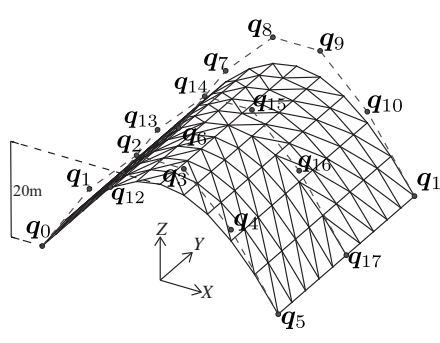

(a) 鳥㒈図
図3 解析モデル

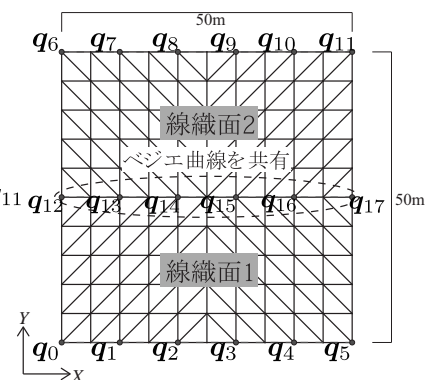

(b) 平面図

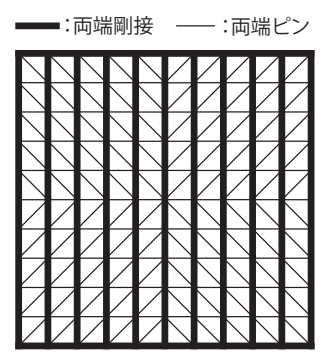

図4 解析モデルの材端条件

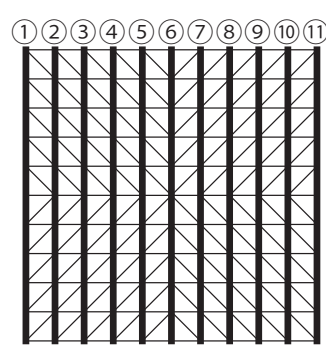

図5 部材のグルーピング
形状表現の自由度を高めるために，曲面を中央で $2 つ の$ 領域に分 け，それぞれの領域において，境界の放物線状のベジエ曲線をそれ ぞれ式 (2)の $\boldsymbol{f}(u), \boldsymbol{h}(u)$ にとった線織面で形状記述し，それらを繋ぎ 合わせた形状とする。すなわち，2 つの線織面は 1 つのべジエ曲線 を共有する。それぞれのべジエ曲線の次数は 5 であり，制御点数は 合計で 18 である。形状は 1 辺 $50 \mathrm{~m}$ の正方形平面を有し，ライズは $20 \mathrm{~m}$ である。変位の境界条件は 4 隅を固定支持とする。

材端条件については，図４に示すように，外周を除く母線間の繋 ぎ材と斜材についてはピン接合とする。これにより，母線方向の部材 


\section{表1 初期形状の弾性解析結果}

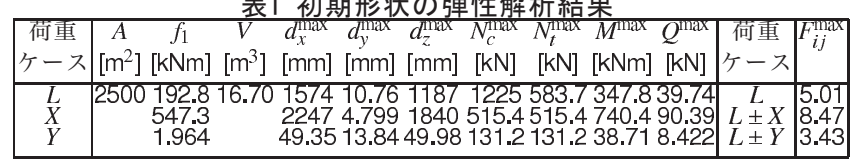

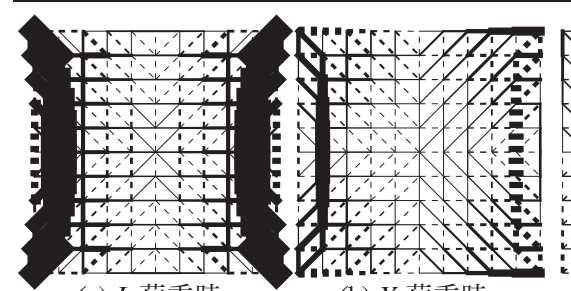

(a) $L$ 荷重時

(b) $X$ 荷重時
図6 初期形状の軸力分布図

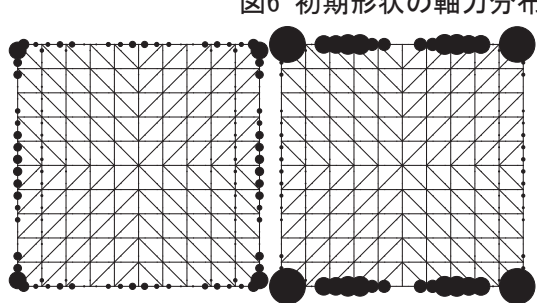

(a) $L$ 荷重時

(b) $X$ 荷重時
図7 初期形状の曲げモーメント分布図

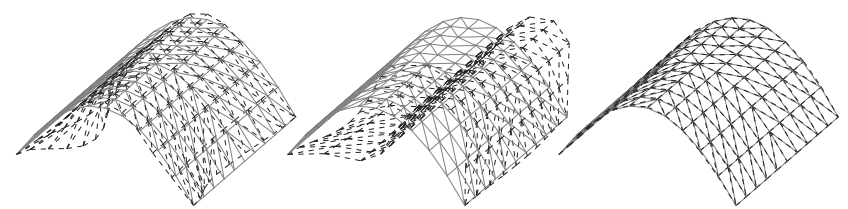

(a) $L$ 荷重時 (b) $X$ 荷重時

図8 初期形状の変位分布図 (c) $Y$ 荷重時

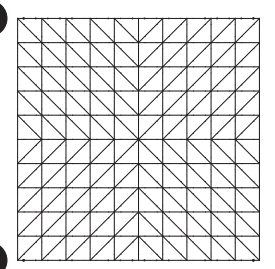

(c) $Y$ 荷重時

(c) $Y$ 荷重時
は，断面形状が同じ場合には通し材として搬入することができ，現 場溶接を削減できる。

式 (8) における節点位置を定めるパラメー夕值 $u_{i}, v_{i}$ はそれぞれ区 間 $[0,1]$ を等分割とし， $u_{i}, v_{i}=0.0,0.1, \cdots, 1.0$ とする。各制御点座標 の $x, y, z$ 成分を並べたベクトルをそれぞれ $\boldsymbol{q}_{x}, \boldsymbol{q}_{y}, \boldsymbol{q}_{z}$ と表す。節点数 は 121 , 自由度数は 702, 部材数は 320 である。初期形状における断 面は全部材とも外径 $267.4 \mathrm{~mm}$, 厚さ $9 \mathrm{~mm}$ の円形鋼管とし, ヤング係 数 $210 \mathrm{GPa}$, ポアソン比 0.30 , 単位体積重量 $77 \mathrm{kN} / \mathrm{m}^{3}, F$ 值 $235 \mathrm{~N} / \mathrm{mm}^{2}$ とする。

$L, X, Y$ の各荷重ケースに対して弾性解析を行った結果を表 1 に 示す。 $A$ はシェルの水平投影面積, $f_{1}$ は問題 $(9)$ における目的関数 であるひずみエネルギー, $V$ は総体積, $d_{x}^{\max }, d_{y}^{\max }, d_{z}^{\max }$ はそれぞれ 各荷重ケースにおける $x, y, z$ 各方向の節点変位の絶対值の最大值, $N_{t}^{\max }, N_{c}^{\max }, Q^{\max }, M^{\max }$ はそれぞれ各荷重ケースにおける引張軸力, 圧縮軸力, せん弾力, 曲げモーメントの絶対值の最大值を表す。な お， $Q^{\max }$ は部材座標 $y, z$ 軸方向それぞれで計算される值の 2 乗和平 方根, $M^{\max }$ は $y, z$ 軸回りそれぞれで計算される值の 2 乗和平方根で ある。部材の検定に際し, 弾性解析で得られた応力から, $L$ の他に, $L+X, L-X, L+Y, L-Y$ の組み合わせ応力を計算し， $L$ を長期荷 重, $L+X, L-X, L+Y, L-Y$ を短期荷重として各部材の検定比を 算出している。 $F_{i j}^{\max }$ は各荷重ケースにおける全部材の検定比の最大 值であり, $L$ は荷重ケース $L$ の検定比の最大值, $L \pm X$ は荷重ケース $L+X, L-X$ それぞれの検定比の最大值のうち大なる值, $L \pm Y$ は荷 重ケース $L+Y, L-Y$ それぞれの検定比の最大值のうち大なる值を
示している。図6〜8 には, 軸力, 曲げモーメント, 変位の分布図を それぞれ示す。軸力図は圧縮力を実線, 引張力を点線で示し, 線の 太さが絶対值の大きさを表している。曲げモーメントは黒円で示し, その直径で 2 軸曲げの 2 乗和平方根の大きさを表している。変位分 布図における実線は変形前の形状, 点線は変形後の形状を表し, 可 視化のために変位を 5 倍にスケーリングしている。本論文では, 7,8 節でも同じルールで結果を表記するものとする。

本解析モデルは, 鉛直荷重に対しては $d_{z}^{\max }$ が $1.2 \mathrm{~m}$ であるのに加 えて, $d_{x}^{\max }$ が $1.5 \mathrm{~m}$ を超えており, 変位分布図を見ると, アーチの根 元の部分が支持点から離れた位置において内側にたわみを生じてい ることが分かる。総じて鉛直剛性は低く, 加えて検定比も 5 を超え ており, 曲げモーメントは端部に局所的に発生し, 存在応力が弾性 範囲に収まっていないことが分かる。水平荷重に対しては， $Y$ 方向加 力時 (母線の方向)においては高い剛性を有し, 斜材がブレースとし て効いて力学的合理性の高い軸抵抗型の力学性状を示している。し かしながら, $X$ 方向加力時 (基底曲線の方向)においては水平剛性が 極めて小さく, $2 \mathrm{~m}$ を超える大変形を生じており, 著しい曲げモーメ ントの発生が主因となって検定比の最大值が 8 を超える結果となつ ている。

\section{7 剛性に対する最適化結果}

式 (9) の最適化問題を考える。体積の上限值, シェルの水平投影面 積の下限值は初期形状での值とし, それぞれ $\bar{V}=16.70 \mathrm{~m}^{3}, \bar{A}=2500 \mathrm{~m}^{2}$ とする。下添え字の 0 は初期形状での值を表す。

\section{1 鉛直荷重に対する最適化結果}

7.1.1 制御点 $z$ 座標を設計変数とした場合 次の最適化問題を考元る。

$$
\begin{array}{ll}
\text { minimize } & f_{1}^{(L)}\left(\boldsymbol{q}_{z}\right) \\
\text { subject to } & g_{1}\left(\boldsymbol{q}_{z}\right) \leq 0 \\
& q_{z, i}=q_{0 z, i} \quad(i=0,5,6,11)
\end{array}
$$

この最適化問題は, 設計変数 $\boldsymbol{x}$ を制御点 $z$ 座標 $\boldsymbol{q}_{z}$ とした, 荷重 ケース $L$ に対する式 (9) の最適化問題である。ただし, 制約 (12c) に よって 4 隅の位置は変更しない。また, 設計変数には形状の $x, y$ 方 向成分を修正する変数を含んで抒らず, 平面形状は変化しないので, 制約 $(9 \mathrm{c})$ は不要である。

最適形状ならびにその力学性状を表 2 , 図 9〜12 に示す。最適化に よって荷重ケース $L$ における弾性変位が減少し, 鉛直剛性が大きく 向上していることが分かる。鉛直変位 $d_{z}^{\max }$ をスパン $L(=50 \mathrm{~m})$ で除し た $d_{z}^{\max } / L$ はおよそ $1 / 1680$ となっており, 鉄骨造の一般的なたわみ制 限值 1/300 と比べて, 十分な剛性を有していると判断できる。また, 剛性の上昇に伴い応力も減少しており, 特に曲げモーメントが消失 し, 主として軸力によって抵抗する力学形態に移行した結果, 検定 比は 1.0 を下回り, 長期荷重に対しては許容応力度設計を満足する 結果となった。

しかしながら, 最適化の対象としなかった水平方向の荷重に対し ては依然として過大な応力が発生しており, 特に $X$ 方向加力時にお いては著しい変形を生じる結果となった。 
表2 問題 (12)の最適形状の弾性解析結果

\begin{tabular}{|c|c|c|}
\hline 荷重 & 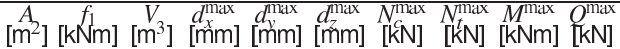 & 荷重 \\
\hline $\begin{array}{l}L \\
X \\
Y\end{array}$ & \begin{tabular}{|cccc}
25006.871 & 16.7018 .9522 .5329 .68282 .789 .72 & 29.6911 .1 \\
535.9 & 2251123.51674855 .4855 .3 & 485.194 .0 \\
35.16 & 117.7138 .8158 .9503 .8503 .8113 .024 .5
\end{tabular} & $\begin{array}{c}L \\
L \pm X \\
L \pm Y\end{array}$ \\
\hline
\end{tabular}

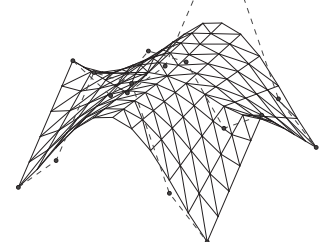

(a) アイソメトリック

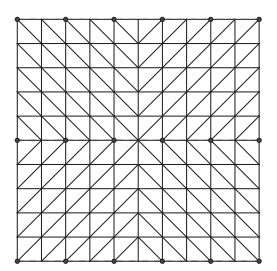

(b) 平面図

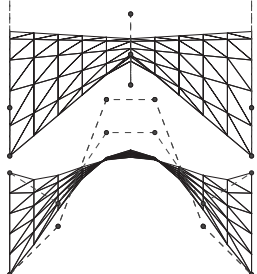

(c) 立面困

図9問題 (12) の最適形状

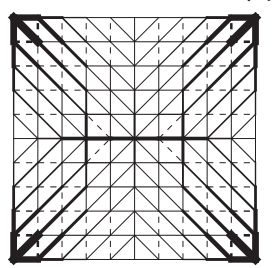

(a) $L$ 荷重時

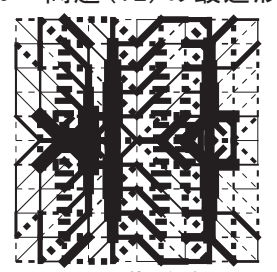

(b) $X$ 荷重時

図10 問題 (12) の最適形状の軸力分布図

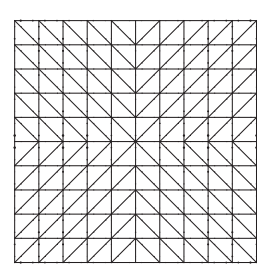

(a) $L$ 荷重時

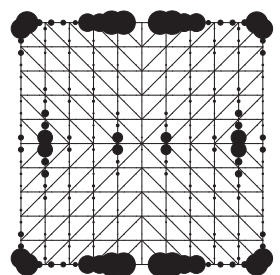

(b) $X$ 荷重時

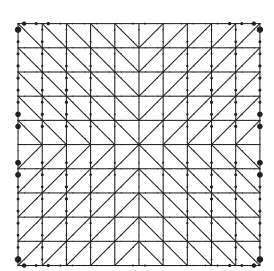

(c) $Y$ 荷重時

図11 問題 (12)の最適形状の曲げモーメント分布図

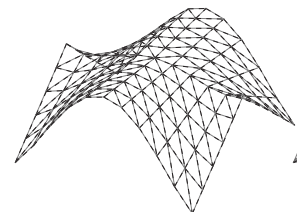

(a) $L$ 荷重時

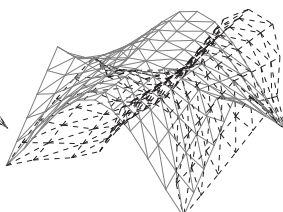

(b) $X$ 荷重時

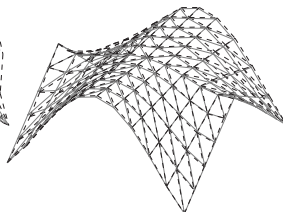

(c) $Y$ 荷重時

図12 問題 (12) の最適形状の変位分布図

7.1.2 制御点 $y, z$ 座標を設計変数とした場合

次の最適化問題を考える。

$$
\begin{array}{ll}
\text { minimize } & f_{1}^{(L)}\left(\boldsymbol{q}_{y}, \boldsymbol{q}_{z}\right) \\
\text { subject to } & g_{1}\left(\boldsymbol{q}_{y}, \boldsymbol{q}_{z}\right) \leq 0 \\
& g_{2}\left(\boldsymbol{q}_{y}\right) \leq 0 \\
& q_{y, i}=q_{0 y, i} \quad(i=0,5,6,11) \\
& q_{z, i}=q_{0 z, i} \quad(i=0,5,6,11)
\end{array}
$$

この最適化問題は, 問題 (12) における設計変数に, 制御点 $y$ 座標 $\boldsymbol{q}_{y}$ を加えたものである。

最適形状ならびにその力学性状を表 3, 図 13〜16にそれぞれ示す。 最適化結果から, 目的関数の值は, 問題 (12) の最適解と比べてわず かに改善されているものの，ほとんど同じ值であることがわかる。 平面方向への形状の修正はわずかであり, 最適形状は問題 (12) の最

\begin{tabular}{|c|c|c|c|c|}
\hline 打重 & $\begin{array}{ccc}A & f_{1} & V \\
{\left[\mathrm{~m}^{2}\right]} & {[\mathrm{kNm}]} & {\left[\mathrm{m}^{3}\right]}\end{array}$ & 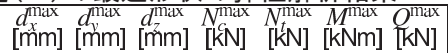 & 荷重 & $F_{i j}^{\mathrm{m}}$ \\
\hline $\begin{array}{l}L \\
X \\
Y\end{array}$ & $\begin{array}{c}25006.63116 .70 \\
387.7 \\
40.79\end{array}$ & 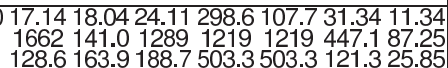 & $\begin{array}{l}L \\
L \pm X \\
L \pm Y\end{array}$ & \\
\hline
\end{tabular}
適形状とほぼ同様な形状となった。力学的な性状についても, 問題 (12) の最適解と同様の傾向を示している。鉛直荷重に対しては, 元 の平面形状が概ね最適であったことがわかる。

表3 問題 (13) の最適形状の弾性解析結果

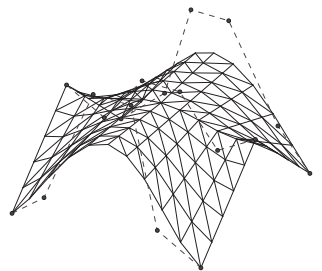

(a)アイソメトリック

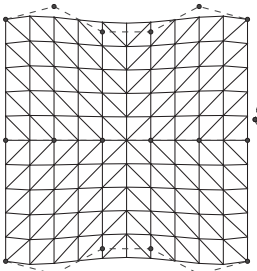

(b) 平面図

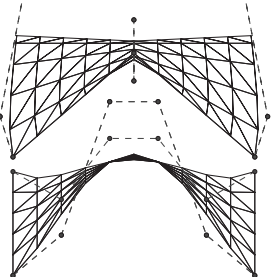

(c) 立面図 図13問題 (13) の最適形状

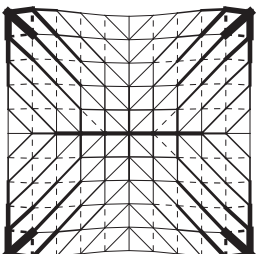

(a) $L$ 荷重時

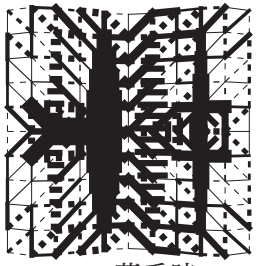

(b) $X$ 荷重時

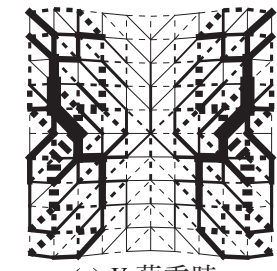

(c) $Y$ 荷重時
図14 問題 (13) の最適形状の軸力分布図

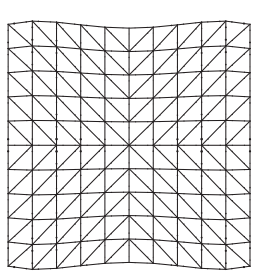

(a) $L$ 荷重時

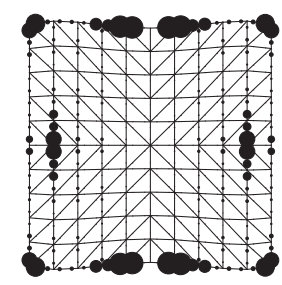

(b) $X$ 荷重時

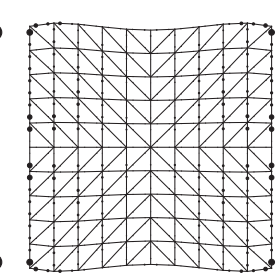

(c) $Y$ 荷重時
図15 問題 (13) の最適形状の曲げモーメント分布図

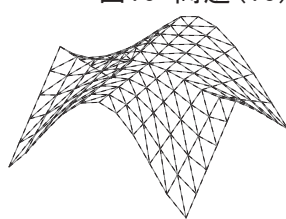

(a) $L$ 荷重時

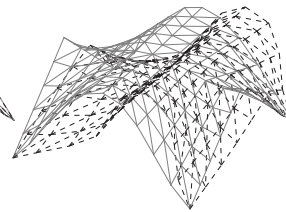

(b) $X$ 荷重時

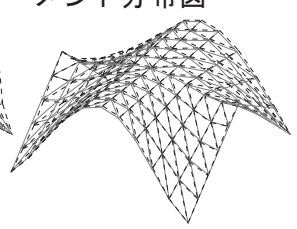

(c) $Y$ 荷重時
図16 問題 (13) の最適形状の変位分布図

7.2 鉛直荷重+水平荷重に対する最適化

7.2.1 制御点 $z$ 座標を設計変数とした場合 次の最適化問題を考える。

$$
\begin{array}{ll}
\text { minimize } & f_{1}^{(L)}\left(\boldsymbol{q}_{z}\right)+f_{1}^{(X)}\left(\boldsymbol{q}_{z}\right)+f_{1}^{(Y)}\left(\boldsymbol{q}_{z}\right) \\
\text { subject to } & g_{1}\left(\boldsymbol{q}_{z}\right) \leq 0 \\
& q_{z, i}=q_{0 z, i} \quad(i=0,5,6,11)
\end{array}
$$

この最適化問題は, 問題 (12) における目的関数に, 荷重ケース $X$, $Y$ ，それぞれにおけるひずみエネルギー值を加えたものである。本最 適化問題により，鉛直剛性，水平剛性の両方の向上が期待できる。

最適形状ならびにその力学性状を表 4, 図 17〜20にそれぞれ示 す。最適化によって荷重ケース $L, X, Y$ それぞれにおける弾性変位を 大幅に減少させることができた。荷重ケース $L$ におけるひずみエネ ルギー值は式 (12) の最適解よりは大きいものの, 荷重ケース $X, Y$ に おけるひずみエネルギー值は大幅に小さくなっており, 鉛直剛性と 水平剛性がバランス良く向上していることが確認できる。最適解は, $f_{1}^{(L)}$ のみを目的関数とした場合と比べ, ライズが低く抑えられてい 
表4 問題 (14)の最適形状の弾性解析結果

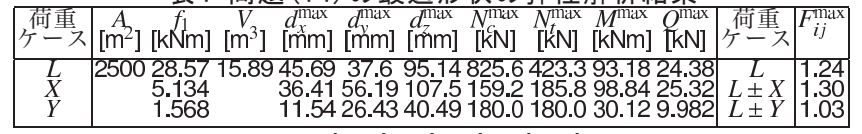

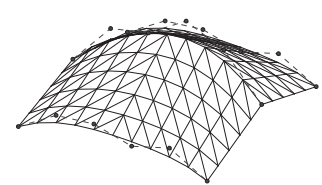

(a) アイソメトリック

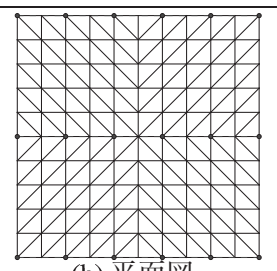

(b) 平面睬

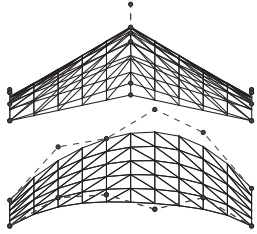

(c) 立面図

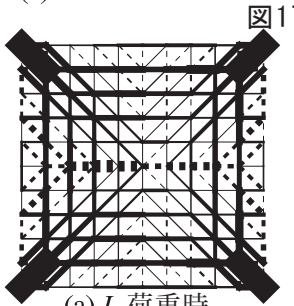

(a) $L$ 荷重時

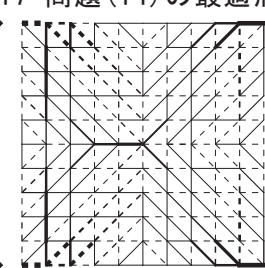

(b) $X$ 荷重時

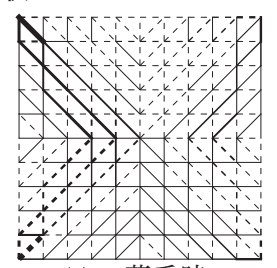

(c) $Y$ 荷重時

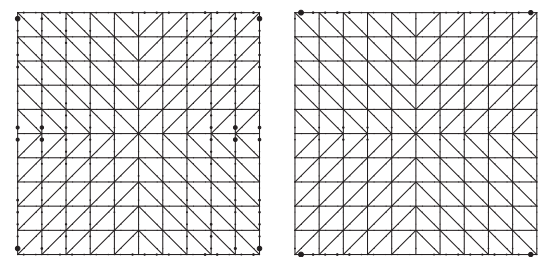

(a) $L$ 荷重時 図19 問題 (b) $X$ 荷重時

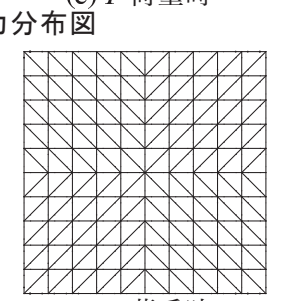

(c) $Y$ 荷重時

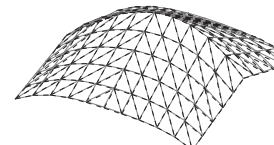

(a) $L$ 荷重時

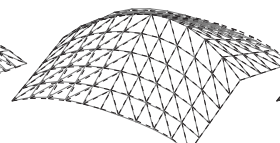

(b) $X$ 荷重時

図20 問題 (14)の最適形状の変位分布図

る。これは，ライズを抑えることで水平加力時に生じる転倒モーメ ントを減少させるためと考えられる。その結果総体積は減少し, 制 約条件 (14b) は不活性となった。鉛直荷重時におけるひずみエネル ギー值を目的関数とした場合と異なり, 形状の対称性が崩れている ことが確認できる。これは, 荷重ケース $L$ と異なり, 荷重ケース $X, Y$ は 1 方向の線形であり, 荷重に方向性を持つためと考えられる。許 容応力度設計は満足できていないものの, 検定比は問題 (12) の最適 解と比べ大幅に減少している。応力分布を見ると, 特に曲げモーメ ントの減少が顕著であり，鉛直，水平いずれの外力に対しても軸力 抵抗型の力学形態となっている。

\subsection{2 制御点 $y, z$ 座標を設計変数とした場合}

次の最適化問題を考える。

$$
\begin{array}{ll}
\text { minimize } & f_{1}^{(L)}\left(\boldsymbol{q}_{y}, \boldsymbol{q}_{z}\right)+f_{1}^{(X)}\left(\boldsymbol{q}_{y}, \boldsymbol{q}_{z}\right)+f_{1}^{(Y)}\left(\boldsymbol{q}_{y}, \boldsymbol{q}_{z}\right) \\
\text { subject to } & g_{1}\left(\boldsymbol{q}_{y}, \boldsymbol{q}_{z}\right) \leq 0 \\
& g_{2}\left(\boldsymbol{q}_{y}\right) \leq 0 \\
& q_{y, i}=q_{0 y, i} \quad(i=0,5,6,11) \\
& q_{z, i}=q_{0 z, i} \quad(i=0,5,6,11)
\end{array}
$$

この最適化問題は, 問題 $(14)$ における設計変数に, 制御点 $y$ 座標 を加えたものである。

最適形状ならびにその力学性状を表 5, 図 21〜24にそれぞれ示

表5 問題 (15)の最適形状の弾性解析結果

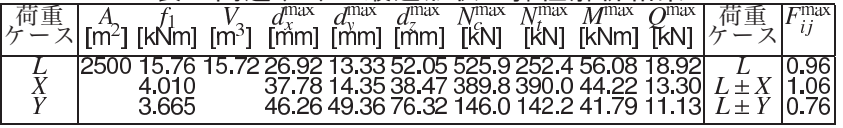

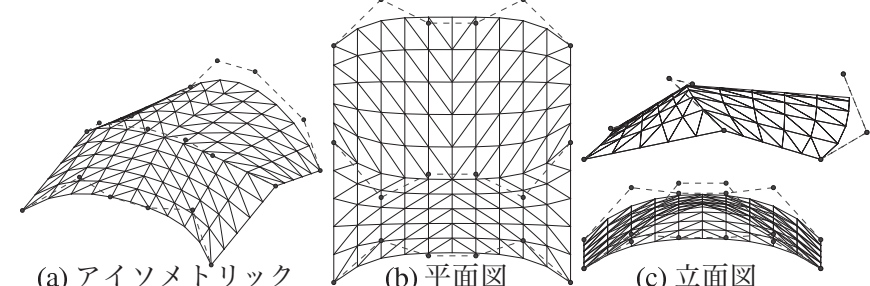
図21問題 (15) 最適形状

(c) 立面困

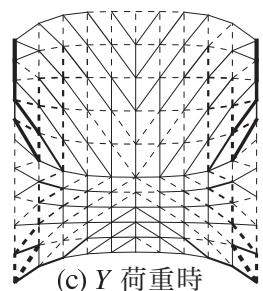

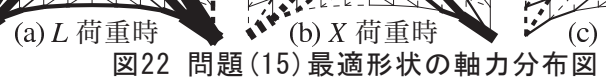

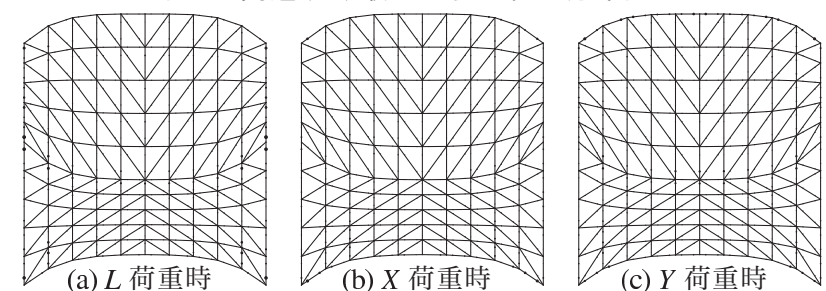
図23問題 (15) 最適形状の曲げモーメント分布図

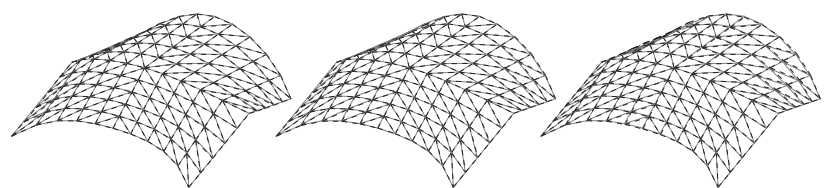

(a) $L$ 荷重時

(b) $X$ 荷重時

(c) $Y$ 荷重時

す。最適化結果から, $z$ 方向のみならず, $y$ 方向にも形状を大きく修 正することで目的関数の值を大幅に低減できていることが分かる。 これは，鉛直荷重のみに対して最適化をおこなった場合には見られ なかった現象である。外力として水平力を考慮した最適化を行う際 には，節点の鉛直方向座標のみならず，水平方向座標を修正するパ ラメータも設計変数として扱うことで, 目的関数の更なる低減が可 能であると言える。岡性の増加とともに, 応力集中も回避されてお り, 検定比の最大值はこれまでの最適解の中で最も小さくなってい るが，X方向荷重時に対しては, わずかながら存在応力が許容応力 度を上回っている。水平荷重を考慮したことで, 最適解は対称性の 崩れた形状となっている。

\section{8 鋼構造設計規準の応力制約を考慮した最適化結果}

7 節で得られた最適解は, いずれもシェルの形状を修正して剛性 のみを最大化したものであるため, 個々の部材に発生する応力は必 ずしも小さくならない。結果として, 検定比が 1 以上となり弾性範 囲を超える応力が発生する部材も存在している。長期荷重のみを考 慮した問題 (12),(13)の最適解は, 結果として長期許容応力度設計は 満足している。一方で, 水平力も考虑した問題 (14),(15) の最適解は, 
表6 問題 (16) 最適形状の弾性解析結果と最適断面分布 ('問題 (14)の 最適解を初期解とした場合)

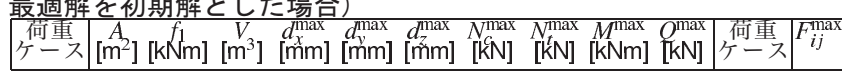

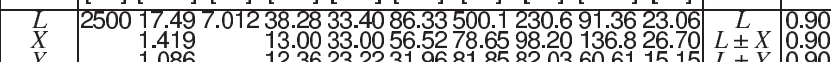

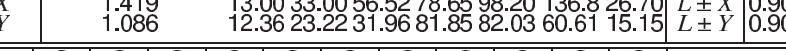

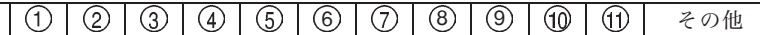
$\bar{R}[\mathrm{~mm}] 309.4272 .8 \mid 189.6$ 175.7 $141.6|112.81112 .8| 171.6|197.6277 .1298 .8| 100.0 \sim 507.5$

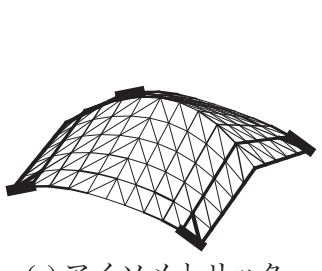

(a) アイソメトリック (c) 立面困

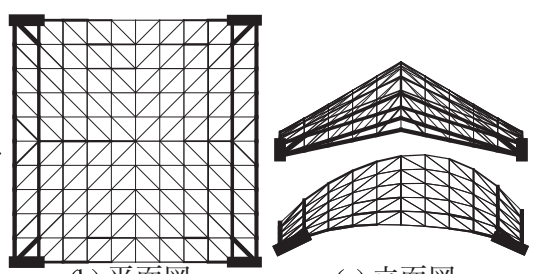

(b) 平面図

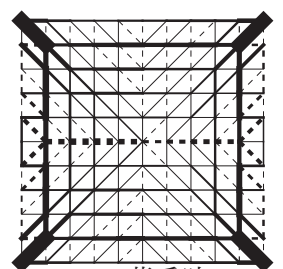

(a) $L$ 荷重時

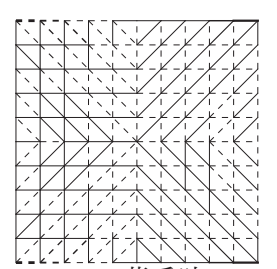

(b) $X$ 荷重時

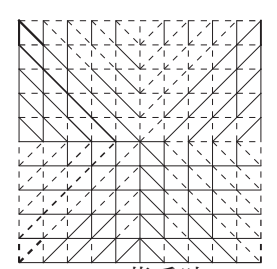

(c) $Y$ 荷重時
図26 問題 (16) の最適形状の軸力分布図 ((14) の最適解を初期解 とした場合)

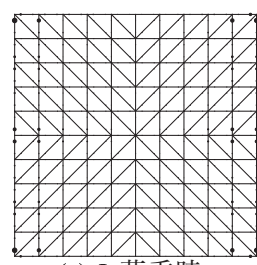

(a) $L$ 荷重時

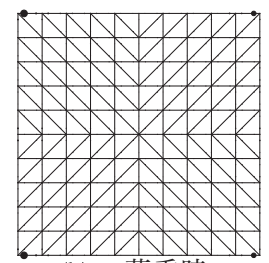

(b) $X$ 荷重時

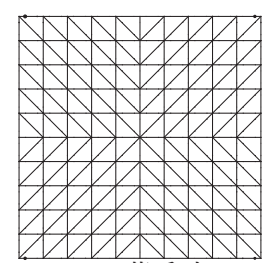

(c) $Y$ 荷重時
図27 問題 (16) の最適形状の曲げモーメント分布図 ((14) の最適解 を初期解とした場合)

水平力に対して高い剛性を獲得しているものの，水平力に対して短 期許容応力度設計は満足できていない。

ここでは, 問題 (14),(15) の最適解に対して, 断面形状を修正する ことで，すべての荷重ケースにおいて検定比を 0.9 以下に抑えつつ も，一定の剛性を有する形態の創生を試みる。部材の鋼管径を並べ たベクトルを $\boldsymbol{R}$ とする。本研究では, 鋼管の径 $R$ と板厚 $t$ との比を, 一般的な流通材の平均的な值として $R / t=27.5$ で固定する。これに より，断面性能をすべて $\boldsymbol{R}$ の関数として記述できる。部材の消失や， 非現実的に巨大な部材の出現を防ぐため， $R$ のとりうる值の範囲を $100 \mathrm{~mm} \leq R_{i} \leq 1000 \mathrm{~mm}$ に設定する。

以上を踏まえ, 次の最適化問題を考える。

$$
\begin{array}{ll}
\text { minimize } & f_{2}(\boldsymbol{R}) \\
\text { subject to } & f_{1}^{(L)}(\boldsymbol{R})+f_{1}^{(X)}(\boldsymbol{R})+f_{1}^{(Y)}(\boldsymbol{R}) \leq \bar{S} \\
& g_{3}(\boldsymbol{R})^{(L)} \leq 0 \\
& g_{3}(\boldsymbol{R})^{(L+X)} \leq 0 \\
& g_{3}(\boldsymbol{R})^{(L-X)} \leq 0 \\
& g_{3}(\boldsymbol{R})^{(L+Y)} \leq 0 \\
& g_{3}(\boldsymbol{R})^{(L-Y)} \leq 0
\end{array}
$$

この最適化問題は，設計変数 $\boldsymbol{a}$ を部材の鋼管径を並べたベクトル $\boldsymbol{R}$ とした，式 (10)の最適化問題である。ひずみエネルギーは, 荷重 ケース $L, X, Y$ それぞれのケースでの合計值を制約する。検定比は,

表7 問題 (16) 最適形状の弾性解析結果と最適断面分布 (問題 (15) 最

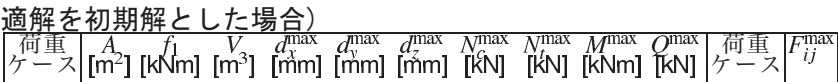
\begin{tabular}{l|lll|l|l|l}
$L$ & 250013.355 .22943 .0024 .8384 .99312 .1169 .146 .6313 .39 & $L$ & 0.90
\end{tabular} \begin{tabular}{l|rrrr|r|}
$X$ & 3.779 & 57.4026 .0872 .78212 .2212 .451 .2611 .76 & $L \pm X$ & 0.90 \\
$Y$ & 2.869 & 65.2560 .8490 .4492 .4388 .3049 .14 & 10.57 & $L \pm Y$ & 0.90 \\
\hline
\end{tabular}

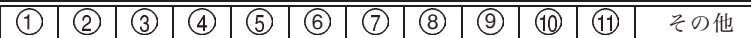

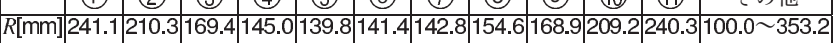

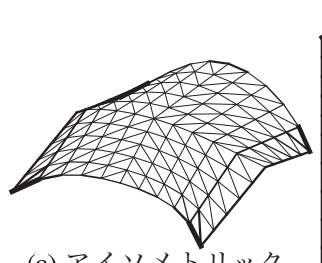

(a) アイソメトリッ少 図28問題 $(16)$ の最適形状
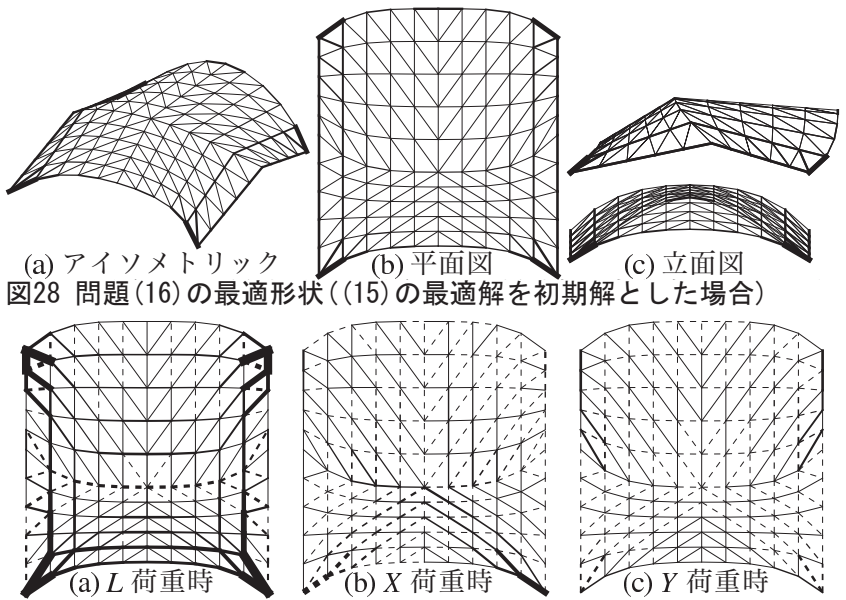

(15)の最適解を初期解とした場合) 図29問題 (16) の最適形状の軸力分布図 ((15) の最適解を初期解とし た場合)
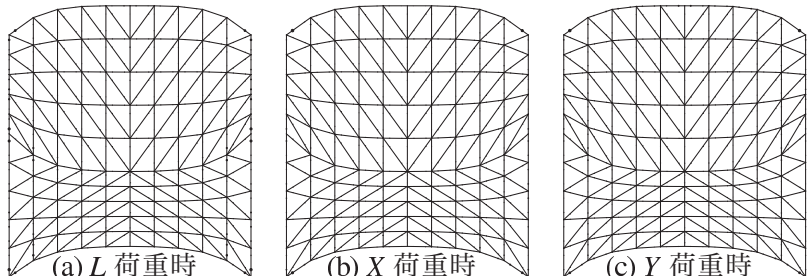

図30 問題 (16) の最適形状の曲げモーメント分布図 ((15) の最適解 を初期解とした場合)

$L$ (長期荷重), $L+X$ (短期荷重), $L-X$ (短期荷重), $L+Y$ (短期荷重), $L-Y$ (短 期荷重) のそれぞれの組み合わせ応力に対して制約を与える。なお, 母線方向の部材については，通し材を想定しているので，変断面と なることは線織面であるメリットを失うことになるため, 図 5 で番号 を付した合計 11 の母線上の部材の $R$ は, それぞれの母線上で同じ值 を取るものとする。ひずみエネルギーの上限值は, 問題 (14),(15) そ れぞれの最適解での值以下となるように， $\bar{S}=20.0 \mathrm{kNm}$ に設定する。

問題 (14) の最適解を初期解とした場合の最適形状ならびにその力 学性状を表 6, 図 25〜27 に，問題 (15) の最適解を初期解とした場合 の最適形状ならびにその力学性状を表 7, 図 28〜30 にそれぞれ示す (変位は微小であるため変位分布図は省略)。図 25,28 における線幅 は，各部材の断面積の大きさを表す。表 6,7 の下段にはグルーピング した部材の鋼管径と, その他の部材の鋼管径の分布を示している。

最適化の結果, 高い剛性を維持し, 許容応力度設計を満足しつつ, 初期解よりも大幅に体積を減少させることが出来た。いずれの最適 解も, 体積が $16.70 \mathrm{~m}^{3}$ からそれぞれ $7.01 \mathrm{~m}^{3}, 5.23 \mathrm{~m}^{3}$ に激減しており, 鋼材量が少なくなり経済性が大幅に向上している。断面形状の分布傾 向としては，外周部材の断面が大きくなり，特に応力の集中する支持 点近傍の部材断面径の上昇が大きく，それぞれ $R=507.5 \mathrm{~mm}, 353.2 \mathrm{~mm}$ となつた。応力の小さい部材についてはいずれも下限值の $R=100 \mathrm{~mm}$ となった。自重の大幅な減少により応力の絶対量は減少しているも のの, 初期形状と比べて応力の分布傾向に大きな変化はない。断面 
形状を設計変数とした最適化は，力の流れそのものに与える影響は それほど大きくはなく, 主として与えられた力の流れに対して適切 な断面性能を付与するものであり, 力の流れを決める要素はシェル の形状が多くを占めていると言える。したがって, シェル形状と断 面形状を同時に設計変数としなくても, シェル形状を最適化したの ちに断面形状を最適化することで十分優良な解が得られると考元ら れる。いずれの最適解も, 図 4 のグループ内の部材断面は同一であ るので, 母線方向の部材は通し材として施工することが可能である。

\section{9 結}

本研究により得られた知見を以下にまとめる。

1、線織面を定める曲線をべジエ曲線で定義することで, 制御点の 位置を定める少ない変数で, さまざまな形状の線織面を表現す ることができる。

2. 線織面を繋ぎ合わせた形状を最適化することで, 単一の線織面 を最適化する場合と比べて実行可能領域を拡大し，様々な形状 を創生することが出来る。

3. 水平力に対しても最適化を行う場合, 鉛直方向だけでなく, 水 平方向にも形状修正を行うことで優良解が得られるが，内部空 間を確保するために水平投影面積の制約が必要である。

4. ひずみエネルギーを最小化することで曲げ，せん断が消失し， 圧縮抵抗型の力学形態に移行する。応力も減少傾向にあるが, 鋼材は圧縮に弱いため, 必ずしも応力度は許容応力度以下とな らない。そのような場合, 断面形状を設計変数として最適化を 行うことで，許容応力度設計を満足することができる。

5. 本手法により得られた最適解はすべて線織面であるので, 母線 方向の部材はすべて同一直線上に存在し，これを通し材とする ことで，通常の自由曲面と比較した場合に比べて高い施工性を 有する。

1 により，本論文で対象としたような規模の構造物であれば，短時間 で最適解を得ることができる。設計変数が少ないので, 鉛直方向の みならず，平面方向の節点座標を修正するパラメー夕を設計変数と した場合においても計算負荷は小さい。2 は, 文献 5)における可展 面の繋ぎ合わせで形成されるシェルの最適化手法の考え方を応用し たものである。1 本物の通し材として製作できる部材の長さは，一般 に現場への搬入トレーラーのサイズで決まり, 高々 $12 \mathrm{~m}$ 程度である ので，12m スパンょりも大きい領域で線織面を繋ぎ合わせれば，継 手の数はあまり変わらない。線織面を複数繋ぎ合わせた形状は，単 一の線織面よりも高い形状表現の自由度を有し，様々な形状を表現 することが可能となる。3について，本論文では取り扱わなかった が, $y, z$ 方向に加えて $x$ 方向にも形状修正を行う場合には, 節点が近 接してしまい極端に短い部材を有する非現実的な形状が得られるこ とが知られており, 本論文で採用した水平投影面積制約以外に, 部 材長に関する制約の導入が必要である7)。また，本論文では，立式 の簡便さから目的関数を $f_{1}^{(L)}+f_{1}^{(X)}+f_{1}^{(Y)}$ という鉛直荷重時と水平 荷重時のひずみエネルギーの線形結合としたが，各荷重時に対する ひずみエネルギー值をバランス良く最小化したい場合には，各荷重 時のひずみエネルギー值に $f_{1}^{(L)} \leq S, f_{1}^{(X)} \leq S, f_{1}^{(Y)} \leq S$ のように上限 值を設け, $S$ を目的関数とする方法も考えられるであろう。4につい て, 許容応力度設計を満足した解を得るためには, 断面形状の最適
化に対する応力制約の導入が必要となる。本論文では最適化手法と して逐次 2 次計画法を採用しているため, 断面形状は連続変数とし て扱った。部材断面形状を離散的に取り扱いたい場合には，発見的 手法や，混合整数計画法などを用いた定式化に基づいて最適化を行 えば良い例えば,20,21)。なお, 今回の解析例では, シェル形状を最適化 した解に対して断面形状を最適化しておりここれは, シェル形状と断 面形状を同時に最適化した場合の最適解とは必ずしも一致しない。5 について，本論文ではラチスシェルを解析対象としたが，本手法は 連続体シェルに対しても容易に適用できると考えられる。

\section{参考文献}

1) M. Ohsaki, T. Nakamura and M. Kohiyama: Shape optimization of a double-layer space truss described by a parametric surface, Int. J. Space Struct., Vol. 12, pp. 109-119, 1997.1

2) 浜田 英明, 大森 博司: 設計者の選好と力学的合理性を勘案した自由曲面 シェル構造の構造形態創生法の提案 その 2 最適性条件による理論的解 法, 日本建築学会構造系論文集, No.618, pp.143-150, 2007.8 .

3) 木村 俊明, 大森博司: 形状と厚さの同時最適化法の定式化とその応用-自 由曲面シェル構造の構造形態創生手法の提案その 1 , 日本建築学会構造系 論文集, No.640, pp.1091-1098, 2009.6.

4) 小河利行，大崎 純，立石 理恵: 線形座屈荷重最大化と部材長一様化を目的 とした単層ラチスシェルの形状最適化, 日本建築学会構造系論文集, No.570, pp.129-136, 2003.8.

5) 藤田 慎之輔，大崎 純: ひずみエネルギーとパラメトリック曲面の代数不 変量を考慮したシェルの形状最適化, 日本建築学会構造系論文集, No.639, pp.857-863, 2009.5

6) P. Basso, A. E. del Grosso, A. Pugnale and M. Sassone: Computational morphogenesis in architecture: Cost optimization of free-form grid shells, Journal of the International Association for Shell and Spatial Structure, Vol.50, No.3, pp. 143150,2009

7) 藤田 慎之輔, 大崎 純: パラメトリック曲面で定義されたラチスシェルの部 材長一様化と剛性最大化を目的とした形状最適化, 日本建築学会構造系論 文集, No.685, pp.495-502, 2013.3.

8) 西森 裕人, 本間 俊雄, 横須賀 洋平: 自由曲面グリッドシェル構造の部材長 一様化と接合角を考慮した形態創生, 日本建築学会構造系論文集, No.721, pp.565-562, 2016.3.

9) 小林昭七: 曲線と曲面の微分幾何, 裳華房, 1995.9.

10) M. Beckh : Hyperboloid Structures, Wiley-Blackwell, 2015.2

11) S. Fujita and M. Ohsaki: Shape optimization of free-form shells using invariants of parametric surface, Int. J. Space Struct., Vol. 25, pp. 143-157, 2010.9

12) B. S. Jiang, J. Hu : A shape optimization based on strain energy for framed structures, Applied Mechanics and Materials, Vol. 578, pp. 532-535, 2014.7

13) 山本憲司, 皆川洋一, 大森博司：座屈荷重を目的関数とする空間構造の 形状最適化に関する研究, 日本建築学会構造系論文集, No.564, pp.95-102, 2003.2

14) 大森博司, 山本憲司: 応力分布を目的関数とする空間構造の形状最適化に 関する研究その 1 シェル構造への適用, 日本建築学会構造系論文集, No.496, pp.67-73, 1997.6

15) 大森博司, 山本憲司 : 応力分布を目的関数とする空間構造の形状最適化 に関する研究その 2 スペースフレームへの適用, 日本建築学会構造系論 文集, No.503, pp.77-83, 1998.1

16) H. Pottmann and J. Wallner : Computational Line Geometry, Springer, 2001.2

17) T. E. Oliphant : Guide to NumPy, Createspace Independent Publishing Platform, 2015.9

18) R. E. Perez, P. W. Jansen, and J. R. R. A. Martins (2012) pyOpt: A Python-based object-oriented framework for nonlinear constrained optimization, Struct. Multidisc. Optim., Vol. 45, pp101-118, 2012.1

19) 寒野善博, 土谷隆 : 最適化と変分法, 丸善出版, 2014.10,

20) 大崎 純: 局所探索法による鋼構造骨組の多目的最適化, 日本建築学会構 造系論文集, No.634, pp.2135-2141, 2009.10

21) Y. Kanno: Mixed-integer second-order cone programming for global optimization of compliance of frame structure with discrete design variables, Struct. Multidisc. Optim., Vol. 53, pp. 1-16, 2015.12 


\title{
SHAPE OPTIMIZATION OF LATTICED SHELLS CONSISTING OF RULED SURFACE
}

\author{
Shinnosuke FUJITA ${ }^{* 1}$, Makoto OHSAKI ${ }^{* 2}$ and Kazuya SEKI ${ }^{* 3}$ \\ ${ }^{* 1}$ Assist. Prof., Laboratory for Future Interdisciplinary Research of Science and Technology, Tokyo Institute of Technology, Dr.Eng. \\ ${ }^{* 2}$ Prof., Dept. of Architecture and Architectural Eng., Kyoto Univ., Dr.Eng. \\ *33 Azusa Sekkei, M.Eng. (Former Grad. Stud., Hiroshima Univ.)
}

Recently, research and practical application of free-form shells are very active owing to development of computer software tools as well as progress of technology of construction and material. Design problem of free-form shells can be naturally formulated as an optimization problem considering mechanical performances. Parametric surfaces such as Bézier surfaces are effectively used for generating smooth and complex surfaces of continuum and latticed shells. However, to design a practically acceptable design, non-structural performances such as cost of construction should be taken into account. In this study, a shape optimization approach is presented for free-form shells using ruled surface. Latticed shells consisting of ruled surface have high constructability, because members on generating lines require no torsion.

Boundary shape of the latticed shell is defined using a pair of Bézier curves to reduce the number of variables. The points with the same parameter value of the two curves are connected by a line to model a ruled surface. The locations of control points of Bézier curves are chosen as design variables.

A latticed shell modeled by ruled surface consisting of two parabolic boundary curves is selected as the initial shape for optimization. Since a simple ruled surface does not have high degree of freedom for shape representation, two ruled surfaces are connected to model a roof with a ridge line. The members of latticed shell is modeled using beam elements, and the four corners are fixed. The vertical self-weight and live loads as well as horizontal loads representing seismic loads are considered in the process of optimization.

First, we minimize the strain energy under volume constraint to obtain a stiff structure. It is confirmed that the strain energy due to vertical and horizontal loads is drastically reduced through shape optimization. Constructability is maintained, because the stiff beams along the generating lines can be manufactured without torsion.

Although a stiff structure is obtained through strain energy minimization, the local stress may not be reduced.

Therefore, we solve the additional optimization problem, which minimizes the material volume under stiffness and stress constraint. The parameter defining the cross-sectional property of each member is considered as design variables of this optimization problem, which is carried out after shape optimization. By solving this problem, the member stresses are reduced through the process of minimizing the material volume, while maintaining the stiffness. 